Studia Judaica 21 (2018), nr 1 (41), s. 159-173

doi:10.4467/24500100STJ.18.009.9179

Agata Rogoś

\title{
Tailoring Identities: \\ Displacement in the Self-Portrayals of Jewish Women Escaping to Albania
}

\begin{abstract}
This article aims to analyze the works of Jewish women autobiographers who wrote about the Holocaust in the context of Albanian cultural tradition. My research appears in the framework of the wider Holocaust women's literature and its strong performance in collective memory studies. Another very important element of these narratives is the reflection on representations of war from a female perspective.

The article focuses on the notion of identity displacement of Jewish women escaping to Albania during World War II and acts of crypto-conversion into the Muslim or Catholic religions. Accordingly, I will concentrate on two autobiographies of Jewish women escaping to Albania: Jutta Neumann and Irene Grünbaum.

These autobiographies are introduced to the reader through an approach of self-portrayal, connecting the issues to the traumatic impact of war and its representations, which serve as a process to conceptualize memory and trauma. One aim here is to show how during World War II in Albania women writers explored the personal and historical impact of these events in autobiographical writings.

The two self-portrayals of Jewish women survivors escaping to Albania presented here emphasize a feminine aspect through proclamations of resistance. Despite the obstacles and difficulties caused by the traditional Albanian social structure and the (dis)placement of the Other, the analyzed narratives are infused with reflections of autobiographers concerning the world immersed in a crisis.
\end{abstract}

Keywords: Albania, Jewish women, identity, Holocaust autobiographies, resistance. 
I ruminated about how strange life was. As many reasons for escaping as there were, I smiled when I thought of the tragicomic situation. Essentially this was a religious struggle between Muslims and Catholics and Jews. Each felt hate and contempt for the other, and the results of these feelings were infamy, war, persecution, and death!

Irene Grünbaum, $1949^{1}$

\section{Introduction}

Official discourses employ images as evidence but also for seduction, blurring fact and fiction to form a powerfully influential narrative and, in essence, to reconstruct reality. The history of the Balkans and more specifically the case of Albania challenge us to reconsider the meaning and importance of representations of war and important shifts in the visualized and semantic meanings of its image in contemporary culture.

In 1914, war still had a human face-the face of the generation of soldiers who fought and died on the battlefields. What can be observed with the development of twentieth-century art, or to put it in other words, what cultural patterns were able to be conveyed in that century, were central shifts in the targets of war, and hence in its killing power. The industrialization of violence-the bombing of civilian targets-became the centerpiece of armed conflict, and genocide became an integral part-a defining part of the war.

This article is dedicated to describing the autobiographical stories of Irene Grünbaum and Jutta Neumann, whose works contribute to the system of representing war and analyzing the mechanisms of their ideas in collective memory. Moreover, these personal stories are rare examples of Jewish women's self-portrayals within the Albanian discourse, transmitting to the reader very important issues connected with the displacement of national and religious identities at the time of the brink of World War II. In addition, this article aims to show the disparity between verified and reconstructed symbolic structures on the basis of personal stories and their functionalization in the collective memory.

The distinction between privileging the voice and privileging the face in representations of terror and its victims is a heuristic one, and as a matter

\footnotetext{
${ }^{1}$ Katherine Morris (ed.), Escape through the Balkans: The Autobiography of Irene Grünbaum (Lincoln-London, 1999), 49.
} 
of fact the history of terror needs to be traced not only through faces but also through the voices of those who knew it from within.

As noted by Victoria Stewart in her comprehensive study on women's autobiography during the war, "the debates about women's writing and the First World War have consisted of a process of retrieval which has not simply meant supplementing the existing 'male canon' but instead has led to a fuller understanding of what the war meant to particular individuals and social groups whose experiences had not previously been examined in detail."2

\section{Frames: Jewish Existence in Albania in the Nazi Period}

Jews in Albania fit into two categories, those who during World War II had been already living in Albania for numerous generations and those who had escaped to Albania because of discrimination and the antisemitic movements spreading throughout Europe. Due to the difficult situation of Jews in all the Balkan territories, a large number of Jews there escaped to Albania to wait through the toughest period, until the political situation allowed them to go further, in most cases to Israel.

According to Bernd Fischer, by the end of World War II approximately 1,800 Jews were living in Albania, numbering at least 1,000 more than in the 1930s. ${ }^{3}$ However, this number is derived mostly from American and Jewish source-based data. ${ }^{4}$ For a full overview on this issue, as suggested by Shaban Sinani, Albanian archive sources should be taken into consideration as well. The documents of the Albanian State Archives cite more than 2,200 Jewish names, mostly family names, proving that the Jewish population in Albania in 1944 must have been much higher than claimed by Fischer and other scholars, e.g. Harvey Sarner ${ }^{5}$ or Michele Sarfatti. $^{6}$

The years 1941-1942 experienced massive displacement and migration flows of Jews from south-eastern Europe, where discrimination was the

${ }^{2}$ Victoria Stewart, Women's Autobiography: War and Trauma (New York, 2003), 4.

${ }^{3}$ Bernd J. Fischer, "The Jews of Albania During the Zogist Period and the Second World War" in James Pettifer, Mentor Nazarko (eds.), Strengthening Religious Tolerance for a Secure Civil Society in Albania and the Southern Balkans (Amsterdam, 2007), 97-100.

${ }^{4}$ Shaban Sinani, Hebrenjtë në Shqipëri: Prania dhe shpëtimi (Tirana, 2009), 66.

${ }^{5}$ Harvey Sarner, Rescue in Albania: One Hundred Percent of Jews in Albania Rescued from Holocaust (Brunswick, 1997).

${ }^{6}$ Laura Brazzo, Michele Sarfatti, Gli ebrei in Albania sotto il fascism: Una storia da ricostruire (Florence, 2010). 
main reason for escaping to Albania. According to Sinani, ${ }^{7}$ one might distinguish three groups of Jewish arrivals to Albania (from Kotor, Dalmatia, and Kosovo) who were trying to avoid the consequences of the spreading Nazi ideology and the risk of the Shoah.

The first such group is referred to in the document collection and correspondence between Luogotenenza (Italian Lieutenancy) and the police departments of several Albanian cities, referring to receiving and the internment of 192 Jews who left Kotor (Yugoslavia) because of the war, and settled in Kavaja.

The second group were Jews who were accepted in Albania in 1941. The group consisted of 350 people staying temporarily in Dalmatia, who thereafter were resettled to Kavaja.

Holocaust studies refer to the massive disappearance of hundreds of Jews from Split who most probably migrated to Albania, according to correspondence between the Albanian government and a branch determining entrance permissions in Pristina for Jews possessing Serbian documents, accredited by Italian diplomatic institutions in Serbia. ${ }^{8}$

The third group mentioned by Sinani ${ }^{9}$ were connected to the Jewish population that lived initially in Kosovo, where, as noted by Bernd Fischer, ${ }^{10}$ about 60 per cent of the Jews were killed.

The high numbers of the Jewish population in Albania could be deduced as well-as stated in the testimony of Johanna (Jutta) Neumann, one of the survivors from Albania-from the fact that a large number of Jews passed through Albania during the war, in search of another place to live. ${ }^{11}$ There were also many cases of Jews not having declared their religious or ethno-cultural status, but instead being registered/registering in official documents as "Aryans."

Albanian archive sources note that in 1943 a person named Proko Jorgo was of Turkish origin, while a certain Polikseni Zacharia was registered as an Aryan. As pointed out by Sinani, ${ }^{12}$ all Jews entering Albania in the 1930s and later were baptized as Christians or were converted formally

${ }^{7}$ Sinani, Hebrenjtë në Shqipëri.

${ }^{8}$ Correspondence between Albanian Council of Ministers and Italian Lieutenancy, 1942, in Arkivi Qendror i Shtetit të Republikës së Shqipërisë [henceforth: AQSH] in Tirana, collection 161, call no. 430, pp. 1-2.

${ }^{9}$ Sinani, Hebrenjtë në Shqipëri, 70.

${ }^{10}$ Fischer, "The Jews of Albania."

${ }^{11}$ Sinani, Hebrenjtë në Shqipëri, 69.

${ }^{12}$ Ibid. 
into Islam while taking on Albanian citizenship. This was also the case with one of the women survivors who escaped to Albania-Irene Grünbaum, who took on a Muslim identity as Fatima Nova: "I was happy to be Fatima Nova, born in Tetovo, the daughter of Sulejman Fekri and the wife of Ali Nova. I went by the name of Fatima Nova until 1945."13

Archival sources also noted some other examples of crypto-conversions into another religion in war-time Albania. In 1929, Albanian nationality was conferred on the family of Moshe Kohen and in 1934 on a Jew of German origin, Frantz Gunjuger, while in 1938 some conversions into the Orthodox Christian religion were registered as well. Concealing members of the Jewish population under another national and/or religious identity in Albania was as a matter of fact a very important part of their displacement-not only in a material (geographical) sense but also through the process of tailoring their identity construction to the new circumstances. The personal story of Jutta Neumann provides an interesting example of the notion of displacement and the clash of identity practices in the private and public spheres-between Judaism and Catholicism:

Indeed the following school year I was one of the pupils of the Convent School, which was being run and taught by Catholic nuns. I had to wear the customary black frock, white collar and a big royal blue bow. We were also expected to salute our teachers whenever we would meet them in the street. During Morning Prayer I, along with all the Muslim children, was permitted to remain seated, but nevertheless I memorized all the prayers. I simply loved the school and felt so good that finally I was like other children, a pupil at school. I remember every day that passed, and felt sad that it would be one less day of school before summer vacation. I learned quickly and soon became the favorite pupil of the nuns. It was considered a big privilege to walk the nuns back to the hospital where they lived. I was asked many times to be my teacher's escort. On several occasions we would stop in church and she would go in and pray. Several times she had asked me to kneel down with her and I consistently refused. I remember her telling me that by just kneeling down nothing would happen ... One time as we were walking together, my teacher said to me that it was very sad that Jews had to suffer so much. It would be much wiser if we all became Catholics and then suffering would stop for us. ${ }^{14}$

The new identity of Jews living in Albania was established not only through religious adherence, but was also reinforced through their official registration as Albanian citizens. A number of archival sources confirm

${ }_{13}$ Morris (ed.), Escape through the Balkans, 47.

${ }^{14}$ Johanna J. Neumann, Escape to Albania: Memoirs of a Jewish Girl from Hamburg (London, 2015), 70-71. 
the issuing of false documents to Jewish families in Kavaja, where in 1944 Salomon Saltiel received a document with the name of Sali Isa, or similar incidents which took place in Tirana and other Albanian cities. The new identity of Jews living in Albania existed on many levels and even influenced some every-day practices and included a new biography that served to authenticate their new self-definition patterns:

Hungry for a scandal, the friends and acquaintances started to interrogate me. "What is your name?" asked a woman, and before I could answer, Hussein Effendi's wife interrupted. "Her name is Fatima, Fatima Nova. Her husband works in the ministry in Tirana. She doesn't speak a word of Albanian, but she is a good Muslim and comes from the Serbian-speaking region. My cousin, Ali Nova, fell in love with her when she was a teacher in the girls' school. He is a modern man. He wanted to see his fiancée even though his parents were against this modern custom. But as you can see, she even travels alone. Oh well, that's modern youth for you." She chatted and lied many times, and the neighbors delighted in hearing this scandal that had taken place in the very respectable Nova family. ${ }^{15}$

At the end of April 1940 an official order was announced for the territory of Albania, demanding that all Jews who had come for a temporary stay leave Albania by 15 May $1940^{16}$ to return to their places of origin or official residence. A significant example of this political turnover is shown in a letter from a German Jewish couple, Leo and Elsa Thur, sent to Pope Pius XII to prevent their deportation to Germany. ${ }^{17}$ As Edmond Malaj ${ }^{18}$ observes, in the early 1940s as a consequence of the change of Albanian policy toward Jews and possible repressions, some Jews in Albania converted either to Catholicism or to Islam. As a result, this formal identity displacement covering the real national and religious self-identification was connected to the changing of names (into Catholic or Muslim names) and the concealing of Jewish identity through the adoption of a cryptoMuslim or crypto-Catholic one.

${ }^{15}$ Morris (ed.), Escape through the Balkans, 45.

${ }^{16}$ Luogotenza Generale di S. M. Il ReImperatore, 1940, in AQSH in Tirana, collection 153, call no. 79 .

${ }^{17}$ Luogotenza Generale di S. M. Il ReImperatore, 1940, in AQSH in Tirana, collection 253, call no. 79 .

${ }^{18}$ Edmond Malaj, Hebrenjtë në trojet shqiptare: Me njëpërqendrim në historinë dhe kulturën hebraike (Shkodër, 2016), 209. 


\section{The Holocaust Autobiographical Tradition}

When one refers to the traumatic impact of war and its representations, there are two important aspects to this kind of process-conceptualization of memory and conceptualization of trauma, which are present not only in all autobiographical portraits, but also in other war representations. In this article, we consider only female autobiographical portrayals as a part of the wider tradition of Holocaust literature. The image of memory will be treated as an artefact to be uncovered in a process of communication between the survivor and the reader/spectator, creating an overall structure that cannot exist beyond this relation. Memories are being recovered in the process of transmission and the presence of self-portraits of Jewish women during the war. As Janice Haaken claims, the storyteller approach situates memory "in the context of narratives and social relationships" and "tends to focus on constellations of preserved knowledge." 19

With the personal stories of Grünbaum and Neumann I aim to show how during the war in Albania women writers explored the personal and historical impact of these events in their autobiographical writing. I analyze how the authors negotiated their positions in light of circumstances which were often either psychologically or physically threatening. The process of falsifying documents and taking crypto-Muslim identities by some Jews living in Albania resulted in an existence based on the permanent fear of being denounced:

I'll send the police to this house so they can get a good look at this guest of the ladies, this teacher from Skopje, the wife of Ali Nova. And she screamed mockingly, "No, you can't fool me! This woman is no teacher and is not Frau Nova. She's one of these damn Jews who suck our blood! She's one of the beasts who has to be exterminated! The Germans will finish you off, finish off the subhumans who nailed our savior to the cross!" ... I wasn't one of those damn Jews. The fact was that I was Fatima Nova. My husband, a high government official in Tirana, would sue her for slander. I advised her to choose her words and actions more prudently. Finally she left. ${ }^{20}$

The notion of reinterpreting or revisiting past events in the continually changing contexts of the present, re-evaluating and reassessing present subjectivity in light of what went before, will be shown as the notion of testimony and an essentially performative process.

19 Janice Haaken, Pillar of Salt: Gender, Memory, and the Perils of Looking Back (New Brunswick-London, 1998), 47.

${ }^{20}$ Morris (ed.), Escape through the Balkans, 48. 
Again I had shown little heroic bravery. Why did people have to scare other people? Hadn't this occurred since the dawn of time, and would it never end? The fact that I wasn't the only one who was afraid was not much consolation to me. Fear was everywhere in this country: in the cities and villages, in the mansions and huts. Fear had crept into farthest corners of the world. Fear was in every heart! And also in every heart was the victor, the oppressor, who today still held the power in his hands but tomorrow or the next hour would be nothing more than a creature who feared death. ${ }^{21}$

The texts I examine are autobiographical portrayals. I explore the elements that make their use of figurative or "literary" language, and their relationship to the "official" discourses of history not straightforward. The relation between the autobiographical portrait and professional history could be considered as a part of collective memory (remembrance) - a cultural act of remembering that not necessarily has to relay or depend on historical events. In analyzing biographies, which can serve also in history studies, the most important aspect is based in fact on the dissonance between history and memory:

A horrible period of tension began after the registration, of course. The Germans had written "Jude" next to everyone's name. So, we all knew what would be awaiting us; we just did not know when. We still did not know at that time that there were death camps. All we knew was that there were forced labor camps. ${ }^{22}$

Thus the storytellers are actors existing in social frameworks of collective actions, which avoids them setting up history and memory in opposition to each other, but also distinguishes between such personally motivated acts of remembrance and those which may have ideological or political overtones: "Cities were bombed and railroads mined, munition depots exploded into the air, people were killed, and no one knew whether he would live through the next day." 23

My focus is thus based on two examples of autobiographical writing which narrate the author's own sense of how her life has been changed by the traumatic events of war:

Would there be no end to this madness? When would people live peacefully again? When would they go to work and spend the evenings with their loved ones? When would one person stop hunting down another? When would this game of hideand-seek with death come to an end ${ }^{24}$

${ }^{21}$ Ibid., 100-101.

${ }^{22}$ Neumann, Escape to Albania, 99.

${ }^{23}$ Morris (ed.), Escape through the Balkans, 53.

${ }^{24}$ Ibid., 51. 
I aim to place my discussion in the context of some recent debates about-and definitions of-autobiography, and specifically women's autobiography, by approaching a case study of displacement in the selfportrayals of Jewish women escaping to Albania.

\section{Autobiography as a Self-Portrayal Representation of War}

When examining autobiographical narratives in a particular context of representations of war, one must realize that the narrator and principal character of the story are identical in terms of retrospective. Autobiographical representations of traumatic events expose and present a portrayal of the autobiographer's life and the ways it had evolved before the act of narrating took place. With the act of exposure of a self-portrayal representation of war, both the author and the reader become part of the process. The autobiographer attempts to enter or re-enter the social, political, and cultural sphere of intersubjectivity, which aims at sharing her life story with the world. Rachel Feldhay Brenner in her study on Holocaust women writers ${ }^{25}$ confirms that by referring to the autobiographer's mental space, the author's consciousness as the narrator of her story redirects attention from her reality to the reality of shaping her emerging story. In the presence of the double role of the autobiographer standing as victim and as writer, we have to refer to her on two levels of acting-communicating and following the creative process of re-entering narratives of remembrance and social bonding.

When analyzing autobiographies, one should first pose a question: what are or were the specific messages that these self-portrayals tried to communicate in a particular and general context? Another important issue connected with analyzing Holocaust autobiographies in their specific cultural and political context (here: the Albanian cultural landscape) is the approach of the storyteller and her means of communication for breaking up the silencing oppression between external violence and internal fear: "Life never returned to normal again! The fear, the terrible fear, which affected my childhood, probably never left me. If anything, it was steadily reinforced by events throughout the war years."26

25 Rachel F. Brenner, Writing as Resistance. Four Women Confronting the Holocaust: Edith Stein, Simone Weil, Anne Frank, Etty Hillesum (Pennsylvania, 1997).

${ }^{26}$ Neumann, Escape to Albania, 41. 
Distance from the atrocity determined by the form of autobiography (which is not the same in the case of a diary, as a diary is written in the real time of actions and life events) allows the authors to construct selfportraits as completed narratives. This kind of retrospect gives the writer a chance to select the most important circumstances and elements of autobiography and to build up the structure of the text, aiming to transfer specific messages to the reader, as in the final part of Irene Grünbaum's self-portrayal:

Farewell, Albania. One day I will tell the world how brave, fearless, strong and faithful your sons are; how death and the devil can't frighten them. If necessary, I'll tell you how they protected a refugee and wouldn't allow her to be harmed even if it meant losing their lives. The gates of your small country remained open, Albania. Your authorities closed both eyes, when necessary, to give poor, persecuted people another chance to survive the most horrible of all wars. Albania, we survived the siege because of your humanity. We thank you. ${ }^{27}$

\section{Displaced Identities - Two Case Studies}

Was I not happier than the many nameless ones who were rotting somewhere? Was it not my duty to live, to fight, to tell about what happened?28

Grünbaum's point of view—quite different from that of men-indicates the way she dealt with the problems a woman faces when traveling alone. Apart from its representations of war, the narrative also shows her courage and the colorful characters she encountered in the Balkans. ${ }^{29}$ Grünbaum's and Neumann's Balkan chronicles are unique contributions to the field of Holocaust history. Escape through the Balkans and Escape to Albania are stories of how Jewish women escaped the Nazis. Survivors of terrible tragedies share certain characteristics, the most notable of which is the desire to bear witness to the ordeal, which arises, as shown in Holocaust studies, from the need to keep the memory of the victims alive. Here, silence is perceived mostly as surrender. What is important in Grünbaum's and Neumann's self-portrayals is the fact that they describe their own situation and view their experience as a part of the experience of all Jews.

Both of the autobiographies contain introductory remarks that proclaim objectives of each autobiographical portrait, explaining both the reason

\footnotetext{
${ }^{27}$ Morris (ed.), Escape through the Balkans, 139.

${ }^{28}$ Ibid., XXI.

${ }^{29}$ Ibid., VI-VII.
} 
for and the context of messaging the history of resistance and survival of the Holocaust. But is it possible to create at the same time within the framework of literature, as stated by Susan Sontag, ${ }^{30}$ an objective record or personal testimony-a precise copy of the fragmented reality or its interpretation? Can we perceive the self-portrayals of Jewish women escaping to Albania as windows into the war? Or is it the other way round-through the fragmented images of war and factual narrative can one see the displacement of their identities and the struggle of resistance?

In the personal histories of two Jewish women escaping to Albania there appears a very important occurrence, which is the impossibility of the autobiographers' place, or to put it differently, their religious and national displacement. For most of the Jewish population the political situation induced by World War II meant living in danger because of their cultural and ethnic origins, which in turn forced them to exist as outcasts of their native states:

Where shall I begin? Shall I describe how serenely and happily I lived in Belgrade with my husband Bobby? How nice my small home was, how good marriage was, how I believed that life would continue so forever? No it didn't continue forever, it couldn't go forever, because Hitler had decided the fate of millions of people, including mine, because I'm a Jew, a child of Jewish parents and married to a Jew. How well I remember 23 March 1941. Revolution in Yugoslavia! The people are beside themselves. They are screaming in the streets: Bolje rat nego pakt. They would have it soon. By the morning of 6 April the war had already begun. I couldn't sleep Saturday night. Fear and panic seized all of us. The brutal surprise attack that followed was worse than we had imagined, and its aftermath was more horrifying than we had imagined, and its aftermath was more horrifying than we had dreamed in our most hideous nightmares. ${ }^{31}$

The process of displacement in the analyzed case might be referred to on two levels. The first level is national placement/displacement and the adherence to a certain cultural tradition which the authors were forced to abandon: "Both my father and mother made tremendous efforts to observe tradition as much as possible and run a religious home. We never missed keeping Shabbat and I don't remember my mother ever failing to light Shabbat candles, even if by doing so she would expose our identity." 32

\footnotetext{
${ }^{30}$ Susan Sontag, Regarding the Pain of Others (New York, 2003), 35.

${ }^{31}$ Morris (ed.), Escape through the Balkans, 3.

${ }^{32}$ Neumann, Escape to Albania, 82.
} 
The second one was religious displacement, which by contrast was a simulation of displacement, existing only in the public sphere; nevertheless, it had had a very important impact on the process of tailoring identities of the Jewish women living in Albania. The new situation of living in Albania, in a Muslim environment, made Grünbaum confront her Jewish origins, which she had deliberately detached herself from, motivated by the predicament of religious identity displacement: "NNow put on your feredža! You'll have to walk a short way with me, and you'll be back here in half an hour,' he said politely. I forgot my aches and pains and went out with the young man, while the others waited, full of hope and curiosity." 33

In the portrayals of Grünbaum and Neumann, as well as in many other autobiographical narratives, apart from direct messages there also appear unstated assumptions which create a horizon of the fragmented histories and are uncovered only in the process of interaction created in the borderland between the autobiographer, the object (in this particular case the written story), and the receiver of the message-the reader. However, the portrait needs to be discovered through an alternative reading of the text.

By establishing their intentions in the introductory note, the autobiographers transmit the explicit message to the receiver (reader), while leaving some traces unstated, which in the analyzed cases constitute the issues of religious displacement.

The question to pose here is connected to the uncommonness of selfportrayals analyzed first in the context of Albanian cultural tradition and second by grounding these stories inside the tradition of Jewish female autobiographers. Considering the Albanian tradition of autobiography, it would be difficult to find any kind of presence of Jewish literature in the overall literary tradition of Albanians.

The two works are structurally and semantically grounded in the tradition of Jewish female autobiographers. Structured in the chronological, factual rendition of a life story, both begin with the generation of parents/ grandparents and the story of a youngster who is a member of a closely related family, which gives to the personal story an important element of the contextualization of shared experiences in a wider cultural context: "I, the Jew, knew how to save my skin and had it in my blood from many generations back: shrewdness, diplomacy, quick thinking and decision making were the weapons my ancestors had handed down to me." ${ }^{34}$

\footnotetext{
${ }^{33}$ Morris (ed.), Escape through the Balkans, 47.

${ }^{34}$ Ibid., 48.
} 
Characteristic not only of those two self-portrayals but also of the entire tradition of Jewish women autobiographers ${ }^{35}$ is that their informative testimony is an important source to be further used in studies on oral history and biographical writing in general, and in the Albanian cultural context, the social relations and presence of the Other and functionalization in the Albanian discourse.

The most important parts of the two autobiographies cover the personal experiences of young Jewish women forced to live in a completely unfamiliar and uncanny reality marked by significant differences in relation to the homeland of the two refugees, most of all in terms of the religious and socio-political displacement which Grünbaum and Neumann experienced in their host country: "It was in these moments that I first fully realized how totally alone I was-alone with my thoughts, my decisions, and actions. I was all alone, without Bobby." 36

Several themes might be referred to as constituting a new selfdefinition characterized in this paper as tailored identity, namely the identity components gathered around the main theme of these personal stories - the notion of displacement. In the process of spatial translocation, or the requisite journey to Albania, the authors reach across to the others-other survivors escaping from different parts of Europe, which is the first important part of the new identity construction of the displacement.

They face the very important question of re-entering subjectivity of social bounds-what are the new social structures that impact self-defining processes in the extraneous circumstances of wartime in Albania?

Another element of the tailored identity which is apparent mostly in the self-portrayal of Grünbaum are the issues of God, fear, and the anxiety of the awaiting exile, influencing the author's further steps and social relations created during the displacement:

I was so tired. I was profoundly tired of everything. But it wasn't sleep that I needed. I needed peace, security, no more fleeing from enemies, I needed to be able to live with nice people near me, I needed a corner for myself alone. But was there still such a place in the world for a Jewish woman? I lay on the strange bed and tried to focus my attention on my situation and to think about it. But my thoughts always wandered. Why did people hunt each other down? Hadn't God created the

\footnotetext{
${ }^{35}$ See Brenner, Writing as Resistance; and Stewart, Women's Autobiography.
}

${ }^{36}$ Morris (ed.), Escape through the Balkans, 50. 
world for all creatures? Had he forgotten something? Why were there prosecutors and prosecuted? Where was God's justice, his love, his omnipotence? Where were miracles that we had learned about in school? ${ }^{37}$

The most important aspect of both autobiographies is perhaps the impossibility of the autobiographer's place as a Muslim or Christian and the reflection on to what extent she sought to reduce her fear of loneliness and degradation as an outcast. In this context the isolation (displacement) serves as a special means for reconnecting to the world while emphasizing a politically discredited identity of a Jew during the war, through which the authors convey their socio-religious message to the world of resistance practices.

\section{Conclusions}

Susan Sontag ${ }^{38}$ when writing about retrospections of war poses several questions about the differences of perception of war and its affective power in male and female narratives. Is it possible, asks Sontag, to stimulate anyone to actively condemn and oppose the war through the power of image or a collection of images? ${ }^{39}$

Probably war narratives and storytelling in contrast to images will have a stronger impact on the perception of trauma, mostly due to the time one has to devote to reflect and sense all its components.

What is then the role of the spectator/receiver of such images and semantic codes which are disseminated by portrayals and self-portrayals influenced by the experience of war? In answering this question, Sontag affirms that every one of "us" who has not gone through this kind of situation that "they" experienced is not able to understand it.

Subjective images recognized by most people according to the memory of war are, with reference to Sontag, ${ }^{40}$ a constituent part of what a society chooses to think about or declares that it has chosen to think about. As a result, ideologies and political discourses create sustaining archives of images, representative images, and narratives, which encapsulate common ideas of significance. ${ }^{41}$

\footnotetext{
37 Ibid., 68-69.

${ }^{38}$ Sontag, Regarding the Pain of Others.

39 Ibid., 144.

${ }^{40}$ Ibid.

${ }^{41}$ Ibid., 85-86.
} 
The two self-portrayals of Jewish women survivors escaping to Albania presented and discussed here emphasize the feminine aspect by a proclamation of resistance. Despite the obstacles and difficulties caused by the traditional Albanian social structure and the (dis)placement of the Other, the narratives are infused with the reflections of autobiographers concerning the world immersed in a crisis.

Agata Rogoś

Humboldt-Universität zu Berlin Adam Mickiewicz University in Poznań rogosaga@hu-berlin.de 